\title{
Opportunity Discovery, Entrepreneurial Action, and Economic Organization
}

\author{
Peter G. Klein \\ Division of Applied Social Sciences and \\ McQuinn Center for Entrepreneurial Leadership \\ University of Missouri \\ Columbia, MO 65211 USA \\ 15738827008 \\ 15738823958 (fax) \\ kleinp@missouri.edu
}

This version: 5 June 2008

Strategic Entrepreneurship Journal, forthcoming

\begin{abstract}
This paper reviews and critiques the "opportunity discovery" approach to entrepreneurship and argues that entrepreneurship can be more thoroughly grounded, and more closely linked to more general problems of economic organization, by adopting the Cantillon-KnightMises understanding of entrepreneurship as judgment. I begin by distinguishing among occupational, structural, and functional approaches to entrepreneurship and distinguishing among two influential interpretations of the entrepreneurial function, discovery and judgment. I turn next to the contemporary literature on opportunity identification and argue that this literature misinterprets Kirzner's instrumental use of the discovery metaphor and mistakenly makes "opportunities" the unit of analysis. I then describe an alternative approach in which investment is the unit of analysis and link this approach to Austrian capital theory. I close with some applications to organizational form and entrepreneurial teams.
\end{abstract}

I thank Jay Barney, Nicolai Foss, Jeffrey Herbener, Joseph Mahoney, Mario Mondelli, Joseph Salerno, Sharon Alvarez (guest editor), two anonymous referees, and participants at the 2007 Washington University Conference on Opportunity Discovery and 2007 Academy of Management meetings for comments on previous versions. 


\section{Opportunity Discovery, Entrepreneurial Action, and Economic Organization}

Entrepreneurship is one of the fastest-growing fields within economics, management, finance, and even law. Surprisingly, however, while the entrepreneur is fundamentally an economic agent — the “driving force of the market,” in Mises’s (1949, p. 249) phrase-modern theories of economic organization and strategy maintain an ambivalent relationship with entrepreneurship. It is widely recognized that entrepreneurship is somehow important, but there is little consensus about how the entrepreneurial role should be modeled and incorporated into economics and strategy. Indeed, the most important works in the economic literature on entrepreneurship-Schumpeter's account of innovation, Knight’s theory of profit, and Kirzner's analysis of entrepreneurial discovery — are viewed as interesting, but idiosyncratic insights that do not easily generalize to other contexts and problems.

The awkward relationship between mainstream economics and entrepreneurship makes sense in the context of the development of the neoclassical theory of production and the firm. The increasingly formalized treatment of markets, notably in the form of general equilibrium theory, not only made firms increasingly "passive," it also made the model of the firm increasingly stylized and anonymous, doing away with those dynamic aspects of markets that are most closely related to entrepreneurship (O’Brien, 1984). In particular, the development of what came to be known as the "production function view” (Williamson, 1985; Langlois and Foss, 1999)_ roughly, the firm as it is presented in intermediate microeconomics textbooks with its fully transparent production possibility sets — was a deathblow to the economic theory of entrepreneurship. If any firm can do what any other firm does (Demsetz, 1988), if all firms are always on their production possibility frontiers, and if firms always make optimal choices of input combinations and output levels, then there is nothing for the entrepreneur to do. Even in more advanced models of asymmetric production functions, hidden characteristics, and strategic interaction, firms or agents are modeled as behaving according to fixed rules subject to formalization by the analyst. The entrepreneur makes an occasional appearance in business history and in Schum- 
peterian models of innovation and technical change, but is largely absent from contemporary economic theory.

One exception is the "Austrian” school of economics, which has given the entrepreneur a central role in the economy at least since the proto-Austrian contribution of Richard Cantillon (1755). Key figures in the Austrian school such as Carl Menger (1871), Eugen von BöhmBawerk (1889), Ludwig von Mises (1949), and Murray Rothbard (1962) all emphasized the entrepreneur in their "causal-realistic" analysis of economic organization and economic change. More recently, the Austrian economist Israel Kirzner has popularized the notion of entrepreneurship as discovery, or alertness to profit opportunities. Kirzner's interpretation of Mises has been highly influential, not only within the Austrian school but also in the "opportunity-discovery" or opportunity-recognition branch of the entrepreneurship literature (Shane and Venkataraman, 2000; Gaglio and Katz, 2001; Shane, 2003).

However, as described below, the opportunity-discovery framework is problematic as a foundation for applied entrepreneurship research. Its central concept, the "opportunity,” was intended by theorists such as Kirzner to be used instrumentally, or metaphorically, as a means of explaining the tendency of markets to equilibrate, and not meant to be treated literally as the object of analysis. I argue that entrepreneurship can be more thoroughly grounded, and more closely linked to theories of economic organization and strategy, by adopting the Cantillon-KnightMises understanding of entrepreneurship as judgment, along with the Austrian's school's subjectivist account of capital heterogeneity. The judgment approach emphasizes that profit opportunities do not exist, objectively, when decisions are made, because the result of action cannot be known with certainty. Opportunities are essentially subjective phenomena (Foss, Klein, Kor, and Mahoney, 2008). As such, opportunities are neither "discovered" nor "created" (Alvarez and Barney, 2007), but imagined. They exist, in other words, only in the minds of decision-makers. Moreover, the essentially subjective character of profit opportunities poses special challenges for applies research on the cognitive psychological aspects of discovery. Rather, I argue, opportuni- 
ties can be treated as a latent concept underlying the real phenomenon of interest, namely entrepreneurial action.

I begin by distinguishing among occupational, structural, and functional approaches to entrepreneurship and explaining two influential interpretations of the entrepreneurial function, discovery and judgment. I turn next to the contemporary literature on opportunity identification, arguing that this literature misinterprets Kirzner's instrumental use of the discovery metaphor and mistakenly makes opportunities the unit of analysis. Instead, I describe an alternative approach in which investment is the unit of analysis and link this approach to the theory of heterogeneous capital theory. I close with some applications to organizational form and entrepreneurial teams.

\section{Entrepreneurship: occupational, structural, and functional perspectives}

To organize the various strands of entrepreneurship literature it is useful to distinguish among occupational, structural, and functional perspectives. Occupational theories define entrepreneurship as self- employment and treat the individual as the unit of analysis, describing the characteristics of individuals who start their own businesses and explaining the choice between employment and self-employment (Kihlstrom and Laffont, 1979; Shaver and Scott, 1991; Parker, 2004). The labor economics literature on occupational choice, along with psychological literature on the personal characteristics of self-employed individuals, fits in this category. For example, McGrath and MacMillan (2000) argue that particular individuals have an "entrepreneurial mindset” that enables and encourages them to find opportunities overlooked or ignored by others (and that this mindset is developed through experience, rather than formal instruction). Structural approaches treat the firm or industry as the unit of analysis, defining the "entrepreneurial firm" as a new or small firm. The literatures on industry dynamics, firm growth, clusters, and networks have in mind a structural concept of entrepreneurship (Aldrich, 1990; Acs and Audretsch, 1990; Audretsch, Keilbach, and Lehmann, 2005). Indeed, the idea that one firm, industry, or economy can be more "entrepreneurial” than another suggests that entrepreneurship is associated with a particular market structure (i.e., lots of small or young firms). 
By contrast, the classic contributions to the economic theory of entrepreneurship from Schumpeter, Knight, Mises, Kirzner, and others model entrepreneurship as a function, activity, or process, not an employment category or market structure. The entrepreneurial function has been characterized in various ways: judgment (Cantillon, 1755; Knight, 1921; Casson, 1982; Langlois and Cosgel, 1993; Foss and Klein, 2005), innovation (Schumpeter, 1911), adaptation (Schultz, 1975, 1982), alertness (Kirzner, 1973, 1979, 1992), and coordination (Witt 1998a, 1998b, 2003). In each case, these functional concepts of entrepreneurship are largely independent of occupational and structural concepts. The entrepreneurial function can be manifested in large and small firms, in old and new firms, by individuals or teams, across a variety of occupational categories, and so on. By focusing too narrowly on self-employment and start-up companies, the contemporary literature may be understating the role of entrepreneurship in the economy and in business organization.

Kirzner's $(1973,1979,1992)$ concept of entrepreneurship as “alertness” to profit opportunities is one of the most influential functional approaches. The simplest case of alertness is that of the arbitrageur, who discovers a discrepancy in present prices that can be exploited for financial gain. In a more typical case, the entrepreneur is alert to a new product or a superior production process and steps in to fill this market gap before others. Success, in this view, comes not from following a well-specified maximization problem, but from having some insight that no one else has, a process that cannot be modeled as an optimization problem. ${ }^{1}$ Because Kirzner's entrepreneurs perform only a discovery function, rather than an investment function, they do not own capital; they need only be alert to profit opportunities. They own no assets, they bear no uncertainty, and hence they cannot earn losses - the worst that can happen to an entrepreneur is the failure to discover an existing profit opportunity. For these reasons, the link between Kirznerian entrepreneurship and other branches of economic analysis, such as industrial organization, inno-

\footnotetext{
${ }^{1}$ Kirzner is careful to distinguish alertness from systematic search, as in Stigler’s $(1961,1962)$ analysis of searching for bargains or for jobs. A nice example is provided by Ricketts (1987, p. 58): “Stigler's searcher decides how much time it is worth spending rummaging through dusty attics and untidy drawers looking for a sketch which (the family recalls) Aunt Enid thought might be by Lautrec. Kirzner's entrepreneur enters a house and glances lazily at the pictures which have been hanging in the same place for years. 'Isn't that a Lautrec on the wall?’”
} 
vation, and the theory of the firm, is weak. Hence Kirzner's concept has not generated a large body of applications. $^{2}$

An alternative account treats entrepreneurship as judgmental decision making under conditions of uncertainty. Judgment refers primarily to business decision making when the range of possible future outcomes, let alone the likelihood of individual outcomes, is generally unknown (what Knight terms uncertainty, rather than mere probabilistic risk). This view finds expression in the earliest known discussion of entrepreneurship, that found in Richard Cantillon's Essai sur la nature de commerce en géneral (1755). Cantillon argues that all market participants, with the exception of landowners and the nobility, can be classified as either entrepreneurs or wage earners:

Entrepreneurs work for uncertain wages, so to speak, and all others for certain wages until they have them, although their functions and their rank are very disproportionate. The General who has a salary, the Courtier who has a pension, and the Domestic who has wages, are in the latter class. All the others are Entrepreneurs, whether they establish themselves with a capital to carry on their enterprise, or are Entrepreneurs of their own work without any capital, and they may be considered as living subject to uncertainty; even Beggars and Robbers are Entrepreneurs of this class (Cantillon, p. 54).

Judgment is distinct from boldness, innovation, alertness, and leadership. Judgment must be exercised in mundane circumstances, for ongoing operations as well as new ventures. Alertness is the ability to react to existing opportunities while judgment refers to beliefs about new opportunities. ${ }^{3}$ Those who specialize in judgmental decision making may be dynamic, charismatic leaders, but they need not possess these traits. In short, in this view, decision making under un-

\footnotetext{
${ }^{2}$ Exceptions include Ekelund and Saurman (1988), Holcombe (1992), Harper (1995), and Sautet (2001).

${ }^{3}$ In Kirzner's treatment, entrepreneurship is characterized as "a responding agency. I view the entrepreneur not as a source of innovative ideas ex nihilo, but as being alert to the opportunities that exist already and are waiting to be noticed" (Kirzner, 1973, p. 74). Of course, as Kirzner (1985, pp. 54-59) himself emphasizes, the actions of entrepreneurs in the present affect the constellation of possible profit opportunities in the future. "[Alertness] does not consist merely in 'seeing' the unfolding of the tapestry of the future in the sense of seeing a preordained flow of events. Alertness must, importantly, embrace the awareness of the ways the human agent can, by imaginative, bold leaps of faith, and determination, in fact create the future for which his present acts are created.” However, Kirzner (1985, p. 57) continues, the only opportunities that matter for equilibration are those that do, in fact, "bear some realistic resemblance to the future as it will be realized.”
} 
certainty is entrepreneurial, whether it involves imagination, creativity, leadership, and related factors or not.

Knight introduces judgment to link profit and the firm to uncertainty. Entrepreneurship represents judgment that cannot be assessed in terms of its marginal product and which cannot, accordingly, be paid a wage (Knight, p. 311). In other words, there is no market for the judgment that entrepreneurs rely on, and therefore exercising judgment requires the person with judgment to start a firm. Judgment thus implies asset ownership, for judgmental decision making is ultimately decision making about the employment of resources. An entrepreneur without capital goods is, in Knight’s sense, no entrepreneur (Foss and Klein, 2005). ${ }^{4}$

Entrepreneurship as uncertainty bearing is also important for Mises’s theory of profit and loss, a cornerstone of his well-known critique of economic planning under socialism. Mises begins with the marginal productivity theory of distribution developed by his Austrian predecessors. In the marginal productivity theory, laborers earn wages, capitalists earn interest, and owners of specific factors earn rents. Any excess (deficit) of a firm's realized receipts over these factor payments constitutes profit (loss). Profit and loss, therefore, are returns to entrepreneurship. In a hypothetical equilibrium without uncertainty (what Mises calls the "evenly rotating economy”), capitalists would still earn interest, as a reward for lending, but there would be no profit or loss.

Entrepreneurs, in Mises’s understanding of the market, make their production plans based on the current prices of factors of production and the anticipated future prices of consumer goods. What Mises calls “economic calculation” is the comparison of these anticipated future receipts with present outlays, all expressed in common monetary units. Under socialism, the absence of

\footnotetext{
${ }^{4}$ It is useful here to distinguish between broad and narrow notions of (Knightian) entrepreneurship. All human action involves judgment, and in an uncertain world, all action places some assets at risk (at minimum, the opportunity cost of the actor's time). In Mises's terminology, human action is the purposeful employment of means to bring about desired ends, which may or may not be realized. In this sense, we are all entrepreneurs, every day. Of course, this broad concept of entrepreneurship is not particularly operational, or empirically important. Economics and organization theorists therefore tend to focus on a narrower concept of entrepreneurship, namely the actions of the businessperson, the investment of tangible resources in pursuit of commercial gain. In the discussion that follows I focus on this narrower, commercial notion of entrepreneurship.
} 
factor markets, and the consequent lack of factor prices, renders economic calculation—and hence rational economic planning-impossible. Mises’s point is that a socialist economy may assign individuals to be workers, managers, technicians, inventors, and the like, but it cannot, by definition, have entrepreneurs, because there are no money profits and losses. Entrepreneurship, and not labor or management or technological expertise, is the crucial element of the market economy. As Mises puts it: directors of socialist enterprises may be allowed to "play market,” to make capital investment decisions as if they were allocating scarce capital across activities in an economizing way, but entrepreneurs cannot be asked to "play speculation and investment” (Mises, 1949, p. 705). Without entrepreneurship, a complex, dynamic economy cannot allocate resources to their highest valued use.

\section{Entrepreneurship as opportunity identification}

While Schumpeter, Kirzner, Cantillon, Knight, and Mises are frequently cited in the contemporary entrepreneurship literature in economics and management (Schultz, by contrast, is rarely cited), much of this literature takes, implicitly, an occupational or structural approach to entrepreneurship. Any relationship to the classic functional contributions is inspirational, not substantive.

The most important exception is the literature in management and organization theory on opportunity discovery or opportunity identification, or what Shane (2003) calls the "individualopportunity nexus.” Opportunity identification involves not only technical skills like financial analysis and market research, but also less tangible forms of creativity, team building, problem solving, and leadership (Long and McMullan, 1984; Hills, Lumpkin, and Singh, 1997; Hindle, 2004). While value can of course be created not only by starting new activities, but also by improving the operation of existing activities, research in opportunity identification tends to emphasize new activities. These could include creating a new firm or starting a new business arrangement, introducing a new product or service, or developing a new method of production. As summarized by Shane (2003, p. 4-5): 
Entrepreneurship is an activity that involves the discovery, evaluation, and exploitation of opportunities to introduce new goods and services, ways of organizing, markets, process, and raw materials through organizing efforts that previously had not existed (Venkataraman, 1997; Shane and Venkataraman, 2000). Given this definition, the academic field of entrepreneurship incorporates, in its domain, explanations for why, when and how entrepreneurial opportunities exist; the sources of those opportunities and the forms that they take; the processes of opportunity discovery and evaluation; the acquisition of resources for the exploitation of these opportunities; the act of opportunity exploitation; why, when, and how some individuals and not others discover, evaluate, gather resources for and exploit opportunities; the strategies used to pursue opportunities; and the organizing efforts to exploit them (Shane and Venkataraman, 2000).

This conception is admirably broad, incorporating not only opportunity discovery, but also the processes by which opportunities are pursued and exploited. What unifies these varied aspects of the entrepreneurial function is the concept of the opportunity. The discovery and (potential) exploitation of opportunities is proposed as the unit of analysis for entrepreneurship research. But what exactly are opportunities? How are they best characterized? How much explicit characterization is necessary for applied research in entrepreneurial organization and strategy?

\section{Opportunities: objective or subjective?}

Shane and Venkataraman (2000, p. 220) define entrepreneurial opportunities as "those situations in which new goods, services, raw materials, and organizing methods can be introduced and sold at greater than their cost of production.” These opportunities are treated as objective phenomena, though their existence is not known to all agents. Shane and Venkataraman also distinguish entrepreneurial opportunities from profit opportunities more generally. While the latter reflect opportunities to create value by enhancing the efficiency of producing existing goods, services, and processes, the former refer to value creation through "the discovery of new meansends frameworks.” Shane and Venkataraman seem to have in mind the distinction between activities that can be modeled as solutions to well-specified optimization problems - what Kirzner (1973) calls "Robbinsian maximizing"-and those for which no existing model, or decision rule, is available. 
However, Shane and Venkataraman appear to misunderstand Kirzner (and the Austrians more generally) on this point. In a world of Knightian uncertainty, all profit opportunities involve decisions for which no well-specified maximization problem is available. Kirzner does not mean that some economic decisions really are the result of Robbinsian maximizing while others reflect discovery. Instead, Kirzner is simply contrasting two methodological constructions for the analysis of human action.

More generally, the opportunity identification literature seeks to build a positive research program by operationalizing the concept of alertness. How is alertness manifested in action? How do we recognize it, empirically? Can we distinguish “discovery” from systematic search? As summarized by Gaglio and Katz (2001):
Almost all of the initial empirical investigations of alertness have focused on the means by which an individual might literally "notice without search.” For exam- ple, Kaish and Gilad (1991) interpret this as having an aptitude to position oneself in the flow of information so that the probability of encountering opportunities without a deliberate search for a specific opportunity is maximized. Therefore, in their operational measures of alertness, they asked founders to recall: (a) the amount of time and effort exerted in generating an information flow; (b) the selec- tion of information sources for generating an information flow; and (c) the cues inherent in information that signal the presence of an opportunity. From this data the authors deduced: (d) the quantity of information in the flow and (e) the breadth and diversity of information in the flow.
Their results conform to expectations in some ways but also reveal some unex- pected patterns. Compared to the sample of corporate executives, the sample of new venture founders do appear to spend more time generating an information flow and do seem more likely to use unconventional sources of information. In- terestingly, the founders do seem more attentive to risk cues rather than to market potential cues. However, the data also reveal that only inexperienced or unsuc- cessful founders engage in such intense information collection efforts. Successful founders actually behave more like the sample of corporate executives. Cooper et al. (1995) found a similar pattern of results in their survey of 1100 firms although Busenitz (1996), in an altered replication of Kaish and Gilad's survey, did not. In- deed Busenitz found few significant differences between corporate managers and new venture founders. In addition, validity checks of the survey measures yielded low reliability scores, which led the author to conclude that future research in alertness required improved theoretical and operational precision.

This positive research program misses, however, the point of Kirzner's metaphor of entrepreneurial alertness: namely, that it is only a metaphor. Kirzner's aim is not to characterize en- 
trepreneurship per se, but to explain the tendency for markets to clear. In the Kirznerian system opportunities are (exogenous) arbitrage opportunities and nothing more. Entrepreneurship itself serves a purely instrumental function; it is the means by which Kirzner explains market clearing. Of course, arbitrage opportunities cannot exist in a perfectly competitive general-equilibrium model, so Kirzner's framework assumes the presence of competitive imperfections, to use the language of strategic factor markets (Barney, 1986; Alvarez and Barney, 2004). Beyond specifying general disequilibrium conditions, however, Kirzner offers no theory of how opportunities come to be identified, who identifies them, and so on; identification itself is a black box. The claim is simply that outside the Arrow-Debreu world in which all knowledge is effectively parameterized, opportunities for disequilibrium profit exist and tend to be discovered and exploited. In short, what Kirzner calls "entrepreneurial discovery" is simply that which causes markets to equilibrate. $^{5}$

Contemporary entrepreneurship scholars, considering whether opportunities are objective or subjective (McMullen and Shepherd, 2006; Companys and McMullen, 2007), note that Kirzner tends to treat them as objective. Again, this is true, but misses the point. Kirzner is not making an ontological claim about the nature of profit opportunities per se-not claiming, in other words, that opportunities are, in some fundamental sense, objective-but merely using the concept of objective, exogenously given, but not-yet-discovered opportunities as a device for explaining the tendency of markets to clear. ${ }^{6}$

The Knightian perspective also treats entrepreneurship as an instrumental construct, used here to decompose business income into two constituent elements, interest and profit. Interest is a reward for forgoing present consumption, is determined by the relative time preferences of bor-

\footnotetext{
${ }^{5}$ The foregoing description applies primarily to what Kirzner calls the "pure entrepreneur." As he explains, fleshand-blood entrepreneurs do not correspond exactly to this ideal type (they can simultaneously be laborers, capitalists, consumers, etc.) and they do more than simply discover costless profit opportunities. However, in Kirzner's framework, the attributes of real-world entrepreneurs defy systematic categorization.

${ }^{6}$ Incidentally, the occupational-choice literature cited above treats opportunities, implicitly or explicitly, as objective. Agents are assumed to compare the expected benefits of employment and self-employment, meaning that the set of possible entrepreneurial outcomes must be fixed and the probability weights assigned to individual outcomes known in advance.
} 
rowers and lenders, and would exist even in a world of certainty. Profit, by contrast, is a reward for anticipating the uncertain future more accurately than others (e.g., purchasing factors of production at market prices below the eventual selling price of the product), and exists only in a world of "true" uncertainty. In such a world, given that production takes time, entrepreneurs will earn either profits or losses based on the differences between factor prices paid and product prices received.

For Knight, in other words, opportunities do not exist, waiting to be discovered (and hence, by definition, exploited). Rather, entrepreneurs invest resources based on their expectations of future consumer demands and market conditions, investments that may or may not yield positive returns. Here the focus is not on opportunities, but on investment and uncertainty. Expectations about the future are inherently subjective and, under conditions of uncertainty rather than risk, constitute judgments that are not themselves modelable. Put differently, subjectivism implies that opportunities do not exist, in an objective sense. Hence a research program based on formalizing and studying empirically the cognitive or psychological processes leading individuals to discover opportunities captures only a limited aspect of the entrepreneurial process. Opportunities for entrepreneurial gain are thus inherently subjective, in the sense that they do not exist until profits are realized. Entrepreneurship research may be able to realize higher marginal returns by focusing on entrepreneurial action, rather than its presumed antecedents. ${ }^{7}$

Alvarez and Barney (2007) argue that entrepreneurial objectives, characteristics, and decision-making differ systematically depending on whether opportunities are modeled as discovered or created. In the “discovery approach,” for example, entrepreneurial actions are responses to exogenous shocks, while in the “creation approach,” such actions are endogenous. Discovery entrepreneurs focus on predicting systematic risks, formulating complete and stable strategies, and procuring capital from external sources. Creation entrepreneurs, by contrast, appreciate itera-

\footnotetext{
${ }^{7}$ Here I follow Gul and Pesendorfer's (2005) more general critique of neuroeconomics, namely that cognitive psychology and economics "address different questions, utilize different abstractions, and address different types of empirical evidence," meaning that the two disciplines are in essentially different, though potentially complementary, domains. In other words, understanding the cognitive processes underlying entrepreneurial behavior may be interesting and important, but not necessary for the economic analysis of the behavior itself.
} 
tive, inductive, incremental decision making, are comfortable with emergent and flexible strategies, and tend to rely on internal finance. ${ }^{8}$

The approach proposed here is close to Alvarez and Barney's creation approach, but differs in that it places greater emphasis on the ex post processes of resource assembly and personnel management rather than the ex ante processes of cognition, expectations formation, and business planning. Moreover, Alvarez and Barney write as if "discovery settings" and "creation settings" are actual business environments within which entrepreneurs operate. Some entrepreneurs really do discover exogenously created profit opportunities while others have to work creatively to establish them. As I read Knight and Kirzner, by contrast, both the discovery and creation perspectives are purely metaphorical concepts, useful for the economist or management theorist, not frameworks for entrepreneurial decision-making itself. This suggests that opportunities are best characterized neither as discovered nor created, but imagined. The creation metaphor implies that profit opportunities, once the entrepreneur has conceived or established them, come into being, objectively, like a work of art. Creation implies that something is created. There is no uncertainty about its existence or characteristics (though of course its market value may not be known until later). By contrast, the concept of opportunity imagination emphasizes that gains (and losses) to not come into being, objectively, until entrepreneurial action is complete (i.e., until final goods and services have been produced and sold). ${ }^{9}$

Moreover, explaining entrepreneurial loss is awkward using both discovery and creation language. In Kirzner's formulation, for example, the worst that can happen to an entrepreneur is the failure to discover an existing profit opportunity. Entrepreneurs either earn profits or break even, but it is unclear how they suffer losses. Kirzner (1997, p. 72) does claim that entrepreneurs can earn losses when they misread market conditions. “[E]ntrepreneurial boldness and imagination

\footnotetext{
${ }^{8}$ Miller (2007) distinguishes further between opportunity recognition, opportunity discovery, and opportunity creation.

${ }^{9}$ The concept of "opportunity imagination” calls to mind Boulding’s (1956) notion of "image," defined as "the sum of what we think we know and what makes us behave the way we do." Human action, in Boulding's framework, is a response to the actor's (subjective) image of reality. This does not mean that images are completely detached from reality, but that reality is filtered, or interpreted, by the actor's subjective beliefs. Penrose's (1959) concept of the firm's "subjective opportunity set" also reflects entrepreneurial imagination, in this sense (Kor, Michael, and Mahoney, 2007).
} 
can lead to pure entrepreneurial losses as well as to pure profit. Mistaken actions by entrepreneurs mean that they have misread the market, possibly pushing price and output constellations in directions not equilibrative.” But even this formulation makes it clear that it is mistaken actions—not mistaken discoveries_- that lead to loss. Misreading market conditions leads to losses only if the entrepreneur has invested resources in a project based on this misreading. It is the failure to anticipate future market conditions correctly that causes the loss. It seems obscure to describe this as erroneous discovery, rather than unsuccessful uncertainty bearing.

Likewise, realized entrepreneurial losses to not fit naturally within a creation framework. Alvarez and Barney (2007) emphasize that “creation entrepreneurs” do take into account potential losses, the “acceptable losses” described by Sarasvathy (2001). “[A]n entrepreneur engages in entrepreneurial actions when the total losses that can be created by such activities are not too large” (Alvarez and Barney, 2007, p. 19). However, when those losses are realized, it seems more straightforward to think in terms of mistaken beliefs about the future-expected prices and sales revenues that did not, in fact, materialize - then the "disappearance” of an opportunity that was previously created. Entrepreneurs do not, in other words, "create” the future, they "imagine” it, and their imagination can be wrong as often as it is right. ${ }^{10}$

\section{Opportunities as a black box}

Confusion over the nature of opportunities is increasingly recognized. As noted by McMullen, Plummer, and Acs (2007, p. 273),

a good portion of the research to date has focused on the discovery, exploitation, and consequences thereof without much attention to the nature and source of opportunity itself. Although some researchers argue that the subjective or socially constructed nature of opportunity makes it impossible to separate opportunity from the individual, others contend that opportunity is as an objective construct visible to or created by the knowledgeable or attuned entrepreneur. Either way, a

\footnotetext{
${ }^{10}$ To go from judgment to an explanation for market efficiency requires assumptions about the tendency of entrepreneurial judgments to be correct. Mises's (1951) explanation is based on a kind of natural namely that market competition rewards those entrepreneurs whose judgments tend to be better than the judgments of their fellow entrepreneurs. Of course, one needn't go as far as Friedman (1953) in assuming that the result is “optimal” behavior, in the neoclassical economist's sense of optimality, to defend the effectiveness of this selection process.
} 
set of weakly held assumptions about the nature and sources of opportunity appear to dominate much of the discussion in the literature.

Do we need a precise definition of opportunities to move forward? Can one do entrepreneurship research without specifying what, exactly, entrepreneurial opportunities “are”? Can we treat opportunities as a "black box,” much as other concepts in management such as culture, leadership, routines, capabilities, and the like are treated (Abell, Felin, and Foss, 2007)?

One approach is to focus not on what opportunities are, but what opportunities do. Opportunities, in this sense, are treated as a latent construct that is manifested in entrepreneurial actioninvestment, creating new organizations, bringing products to market, and so on. A direct analogy can be drawn to the economist's notion of preferences. Economic theory (with the exception of behavioral economics, discussed below) takes agents’ preferences as given and derives implications for choice. The economist does not care what preferences “are,” ontologically, but simply postulates their existence and draws inferences about their characteristics as needed to explain particular kinds of economic behavior. Empirically, this approach can be operationalized by treating entrepreneurship as a latent variable in a structural-equations framework (Xue and Klein, 2007).

By treating opportunities as a latent construct, this approach sidesteps the problem of defining opportunities as objective or subjective, real or imagined, and so on. The formation of entrepreneurial beliefs is treated as a potentially interesting psychological problem, but not part of the economic analysis of entrepreneurship. It also avoids thorny questions about whether alertness or judgment is simply luck (Demsetz, 1983), a kind of intuition (Dane and Pratt, 2007), or something else entirely.

\section{The unit of analysis}

As explained above, the opportunity-creation approach proposed by Alvarez and Barney (2007) differs in important ways from the opportunity-discovery approach. The creation approach treats opportunities as the result of entrepreneurial action. Opportunities do not exist ob- 
jectively, ex ante, but are created, ex nihilo, as entrepreneurs act based on their subjective beliefs. “Creation opportunities are social constructions that do not exist independent of entrepreneur's perceptions" (Alvarez and Barney, 2007, p. 15). In this sense, the creation approach sounds like the imagination approach described here. Still, like the discovery approach, the creation approach makes the opportunity the unit of analysis. How entrepreneurs create opportunities, and how they subsequently seek to exploit those opportunities, is the focus of the research program.

At one level, the distinction between opportunity creation and opportunity imagination seems semantic. Both hold that entrepreneurs act based on their beliefs about future gains and losses, rather than reacting to objective, exogenously given opportunities for profit. There are some ontological and epistemological differences, however. The creation approach is grounded in a social constructivist view of action (Alvarez and Barney, 2007, pp. 15-16). It holds that the market itself is a social construction, and that realized gains and losses are, in part, subjective. The imagination approach described here is, in this sense, less subjectivist than the creation approach. It is tied closely to Mises's $(1912,1920)$ concept of monetary calculation, in which realized gains and losses are objective and quantifiable, and used to filter, or select, the quality of entrepreneurial expectations and beliefs. It is compatible with a range of ontological positions, from evolutionary realism to critical realism (Lawson, 1997; Mäki, 1996) to Misesian praxeology (Mises, 1949).

An alternative way to frame a subjectivist approach to entrepreneurship, emphasizing uncertainty and the passage of time, is to drop the concept of "opportunity" altogether. If opportunities are inherently subjective, and we treat them as a black box, then the unit of analysis should not be opportunities, but rather some action —in Knightian terms, the assembly of resources in the present in anticipation of (uncertain) receipts in the future. Again, the analogy with preferences in microeconomic theory is clear: the unit of analysis in consumer theory is not preferences but consumption, while in neoclassical production theory the unit of analysis is not the production function but some decision variable. 
Alternatively, one could view opportunities and actions as distinct, but complementary, aspects of the entrepreneurial process. To use Alvarez and Barney's (2007) terminology, the discovery perspective treats actions as responses to opportunities, while the creation perspective treats opportunities as the result of action. By contrast, the perspective outlined here treats opportunities as a superfluous concept, once action is taken into account. Opportunities exist only as manifested in action, and are neither its cause nor consequence of action. Hence we can dispense with the very notion of opportunities itself and focus on the actions that entrepreneurs take and the results of those actions.

One way to capture the Knightian concept of entrepreneurial action is Casson's notion of “projects” (Casson, 2007; Casson and Wadeson, 2007). A project is a stock of resources committed to particular activities for a specified period of time. Project benefits are uncertain and are realized only after projects are completed. Casson and Wadeson (2007, p. 289) model the set of potential projects as given, defining opportunities as potential projects that have not yet been chosen. As in the discovery-process perspective, the set of opportunities is fixed. However, as Casson and Wadeson point out, the assumption of fixed "project possibility sets" is a modeling convenience, made necessary by their particular theory of project selection. More generally, the use of projects as the unit of analysis is consistent with either the "discovery" or "creation" perspective. Focusing on projects, rather than opportunities, implies an emphasis on the actions that generate profits and losses. It suggests that entrepreneurship research should focus on the execution of business plans.

In this sense, entrepreneurship is closely linked to finance-not simply "entrepreneurial finance" that studies venture funding and firm formation, but the more general problem of project finance under (true) uncertainty. Not only venture capital but also public equity and debt are entrepreneurial instruments, in this perspective. Capital budgeting is also a form of entrepreneurial decision-making. Of course, contemporary finance theory focuses primarily on equilibrium models of resource allocation under conditions of risk, not Knightian uncertainty, so entrepreneurship theory cannot be simply a reframing of modern finance theory. Instead, a "financiers-as- 
entrepreneurs” approach treats investors not as passive suppliers of capital to decision-making firms, but as the locus of economic decision-making itself, as economic agents who experiment with resource combinations (Klein and Klein, 2001), develop and exploit network ties (Meyer, 2000), manage and govern subordinates (Kaplan and Strömberg, 2003), and the like.

\section{Entrepreneurial action, heterogeneous capital, and economic organization}

The close relationship between the Knightian concept of entrepreneurship as action under uncertainty and the ownership and control of resources suggests a bridge between entrepreneurship and the mundane activities of establishing and maintaining a business enterprise- -what Witt (2003) calls the “organizational grind.” Foss and Klein (2005) and Foss, Foss, Klein, and Klein (2007) offer an entrepreneurial theory of the economic organization that combines the Knightian concept of judgment and the Austrian approach to capital heterogeneity. In Knight's formulation, entrepreneurship represents judgment that cannot be assessed in terms of its marginal product and which cannot, accordingly, be paid a wage (Knight 1921: 311). In other words, there is no market for the judgment that entrepreneurs rely on, and therefore exercising judgment requires the person with judgment to start a firm. Of course, judgmental decision makers can hire consultants, forecasters, technical experts, and so on. However, in doing so they are exercising their own entrepreneurial judgment. ${ }^{11}$ Judgment thus implies asset ownership, for judgmental decision-making is ultimately decision-making about the employment of resources. The entrepreneur's role, then, is to arrange or organize the capital goods he owns. As Lachmann (1956, p. 16) puts it: "We are living in a world of unexpected change; hence capital combinations ... will be ever changing, will be dissolved and reformed. In this activity, we find the real function of the entrepreneur." 12

\footnotetext{
${ }^{11}$ In Foss, Foss, and Klein’s (2007) terminology, the entrepreneur-owner exercises “original” judgment, while hired employees, to whom the owner delegates particular decision rights, exercise "derived" judgment as agents of the owner. This implies that top corporate managers, whose day-to-day decisions drive the organization of corporate resources, are acting only as "proxy-entrepreneurs," except to the extent that they themselves are part owners through equity holdings.

${ }^{12}$ Lachmann (1956) does not require the entrepreneur to own the assets he recombines; see Foss, Foss, Klein, and Klein (2007 for a more detailed argument that ownership, as residual rights of control, is a necessary part of this
} 
Austrian capital theory provides a unique foundation for an entrepreneurial theory of economic organization. Neoclassical production theory, with its notion of capital as a permanent, homogeneous fund of value, rather than a discrete stock of heterogeneous capital goods, is of little help here. ${ }^{13}$ Transaction cost, resource-based, and property-rights approaches to the firm do incorporate notions of heterogeneous assets, but they tend to invoke the needed specificities in an ad hoc fashion to rationalize particular trading problems-for transaction cost economics, asset specificity; for capabilities theories, tacit knowledge; and so on. The Austrian approach, starting with Menger’s (1871) concepts of higher- and lower-order goods and extending through BöhmBawerk’s (1889) notion of roundaboutness, Lachmann’s (1956) theory of multiple specificities, and Kirzner’s (1966) formulation of capital structure in terms of subjective entrepreneurial plans, offers a solid foundation for a judgment-based theory of entrepreneurial action.

One way to operationalize the Austrian notion of heterogeneity is to incorporate Barzel's (1997) idea that capital goods are distinguished by their attributes. Attributes are characteristics, functions, or possible uses of assets, as perceived by an entrepreneur. Assets are heterogeneous to the extent that they have different, and different levels of, valued attributes. Attributes may also vary over time, even for a particular asset. Given Knightian uncertainty, attributes do not

entrepreneurial function. Consider also Marchal's (1951, pp. 550-51) explanation of the economic return to the entrepreneurial function:

[E]ntrepreneurs obtain remuneration for their activity in a very different manner than do laborers or lenders of capital. The latter provide factors of production which they sell to the entrepreneur at prices which they naturally try to make as high as possible. The entrepreneur proceeds quite otherwise; instead of selling something to the enterprise he identifies himself with the enterprise.. Some people doubtless will say that he provides the function of enterprise and receives as remuneration a sum which varies according to the results. But this is a tortured way of presenting the thing, inspired by an unhealthy desire to establish arbitrarily asymmetry with the other factors. In reality, the entrepreneur and the firm are one and the same. His function is to negotiate, or to pay people for negotiating under his responsibility and in the name of the firm, with two groups: on the one hand, with those who provide the factors of production, in which case his problem is to pay the lowest prices possible; on the other hand, with the buyers of the finished products, from which it is desirable to obtain as large a total revenue as possible. To say all this in a few words, the entrepreneur, although undeniably providing a factor of production, perhaps the most important one in a capitalist system, is not himself to be defined in those terms.

Marchal expresses, in strong terms, the view described in Foss, Foss, Klein, and Klein (2007) that entrepreneurship is embodied in asset ownership (i.e., in the creation and operation of the firm). The entrepreneur is not merely an idea man, but rather an owner, who exercises judgment over the capital assets he owns and manages. This contrasts with Kirzner's analytical device of the "pure entrepreneur" who owns no capital. (I thank John Matthews for the reference to Marchal.)

${ }^{13}$ Ironically, the notion of capital as a homogeneous fund owes its popularity to Knight (1936). 
exist objectively, but subjectively, the minds of profit-seeking entrepreneurs who put these assets to use in various lines of production. Consequently, attributes are manifested in production decisions and realized only ex post, after profits and losses materialize. ${ }^{14}$

Entrepreneurs who seek to create or discover new attributes of capital assets will want ownership titles to the relevant assets, both for speculative reasons and for reasons of economizing on transaction costs. These arguments provide room for entrepreneurship that goes beyond deploying a superior combination of capital assets with "given” attributes, acquiring the relevant assets, and deploying these to producing for a market: Entrepreneurship may also be a matter of experimenting with capital assets in an attempt to discover new valued attributes.

Such experimental activity may take place in the context of trying out new combinations through the acquisition of or merger with another firms, or in the form of trying out new combinations of assets already under the control of the entrepreneur. The entrepreneur's success in experimenting with assets in this manner depends not only on his ability to anticipate future prices and market conditions, but also on internal and external transaction costs, the entrepreneur's control over the relevant assets, how much of the expected return from experimental activity he can hope to appropriate, and so on. Moreover, these latter factors are key determinants of economic organization in modern theories of the firm, which suggests that there may be fruitful complementarities between the theory of economic organization and Austrian theories of capital heterogeneity and entrepreneurship.

Foss, Foss, Klein, and Klein (2007) show how this approach provides new insights into the emergence, boundaries, and internal organization of the firm. Firms exist not only to economize on transaction costs, but also as a means for the exercise of entrepreneurial judgment, and as a low-cost mechanism for entrepreneurs to experiment with various combinations of heterogene-

\footnotetext{
${ }^{14}$ As Alchian and Demsetz (1972, p. 793) note, "[e]fficient production with heterogeneous resources is a result not of having better resources but in knowing more accurately the relative productive performances of those resources." Contra the production function view in basic neoclassical economics, such knowledge is not given, but has to be created or discovered. Even in the literature on opportunity creation and exploitation, in which entrepreneurial objectives are seen as emerging endogenously from project champions' creative imaginations, entrepreneurial means (resources) are typically taken as given (see, for example, Sarasvathy, 2001).
} 
ous capital goods. Changes in firm boundaries can likewise be understood as the result of processes of entrepreneurial experimentation. And internal organization can be interpreted as the means by which the entrepreneur delegates particular decision rights to subordinates who exercise a form of "derived” judgment on his behalf (Foss, Foss, and Klein, 2007).

Witt (1998a, 1998b) offers another approach to combining an Austrian concept of entrepreneurship with the theory of the firm. Entrepreneurs require complementary factors of production, he argues, which are coordinated within the firm. For the firm to be successful, the entrepreneur must establish a tacit, shared framework of goals - what Casson (2000) calls a "mental model" of reality—which governs the relationships among members of the entrepreneur's team. As Langlois (1998) points out, it is often easier (less costly) for individuals to commit to a specific individual, the leader, rather than an abstract set of complex rules governing the firm's operations. The appropriate exercise of charismatic authority, then, facilitates coordination within organizations (Witt, 2003). This approach combines insights from economics, psychology, and sociology, and leans heavily on Max Weber. Leaders coordinate through effective communication, not only of explicit information, but also tacit knowledge—plans, rules visions, and the like, what Casson (2000) calls “mental models” of reality. The successful entrepreneur excels at communicating such models. ${ }^{15}$

Here, as in Coase (1937), the employment relationship is central to the theory of the firm. The entrepreneur's primary task is to coordinate the human resources that make up the firm. Foss, Foss, Klein, and Klein (2007), by contrast, focus on alienable assets, as in Knight (1921). They define the firm as the entrepreneur plus the alienable resources the entrepreneur owns and thus controls. Each approach has strengths and weaknesses. The cognitive approach explains the dynamics among team members but not necessarily their contractual relationships. Must the charismatic leader necessarily own physical capital, or can he be an employee or independent contractor? Formulating a business plan, communicating a corporate culture, and the like are clearly

\footnotetext{
${ }^{15}$ Earl's (2003) “connectionist approach” to entrepreneurship also focuses on coordination, but here the emphasis is on coordination among market participants, not within organizations. See also Koppl and Langlois (2001) and Langlois (2002).
} 
important dimensions of business leadership. But are they attributes of the successful manager or the successful entrepreneur? Even if top-level managerial skill were the same as entrepreneurship, it is unclear why charismatic leadership should be regarded as more "entrepreneurial" than other, comparatively mundane managerial tasks such as structuring incentives, limiting opportunism, administering rewards, and so on. On the other hand, the judgment approach does not generalize easily from the one-person firm to the multi-person firm.

\section{Applications of entrepreneurial action}

Shifting the focus of entrepreneurship research from opportunity identification to entrepreneurial action suggests several new issues and directions for entrepreneurship research.

\section{Opportunities and organizational form}

Distinguishing between opportunity discovery and entrepreneurial action reminds us that the two do not always go hand-in-hand. Efforts to encourage the former do not necessarily encourage the latter. Generally, efficiency requires that entrepreneurs (and what Foss, Foss, and Klein 2007 call "proxy-entrepreneurs") bear the full wealth effects of their actions. For this reason, efforts to promote experimentation, creativity, etc. within the firm can encourage moral hazard unless rewards and punishments are symmetric. Outside the firm, strong intellectual-property protection, incentives for discovery such as SBIR awards, and the like may encourage overspending on discovery. The potential waste of resources on "patent races" is a well-known example (Barzel, 1968; Loury, 1979; Dasgupta and Stiglitz, 1980; Judd, Schmedders, and Yeltekin, 2003).

By contrast, if the essence of entrepreneurship is the assembly of resources under uncertainty, then the locus of entrepreneurship is not the generation of creative ideas, but the funding of projects. Financiers—venture capitalists, angel investors, banks, family members, even corporate shareholders-are, in this sense, entrepreneurs. Resource owners possess fundamental judgment rights that, by the nature of ownership, cannot be delegated, no matter how many proximate decision rights are delegated to subordinates (Foss, Foss, and Klein, 2007). In this perspective even corporate shareholders are treated not as passive suppliers of capital, as they are treated 
both in neoclassical production theory and in contemporary entrepreneurship theory, but as critical decision makers. ${ }^{16}$

Some applications, such as the staging of venture finance (Gompers, 1995), are obvious. Another application is the inherent uncertainty of the gains from corporate takeovers. In the absence of uncertainty, one can imagine an equilibrium in which the number of takeovers is suboptimal because shareholders will refuse to tender their shares for anything less than their share of the post-takeover value of the firm (Scharfstein, 1988). In a world of Knightian uncertainty, however, the post-takeover value of the firm is uncertain, and many shareholders, not wanting to bear this uncertainty, will tender their shares to the "raider" at a price above the pre-takeover share value but below the raider's expected post-takeover price. The raider's return to a successful takeover is thus a form of pure entrepreneurial profit (Klein, 1999, pp. 36-38).

Note that in this perspective, finance is treated not as an input into the entrepreneurial process, but as the very essence of that process. Entrepreneurship is, in other words, manifested in investment. Of course, the terms "finance" and "investment" are used here in a broad sense, referring to the provision not only of financial capital, but also human capital, tangible and intangible resources, and the like-anything that can be considered an input or factor of production. Entrepreneurship is conceived as the act of putting resources at risk, with profit as the reward for

\footnotetext{
${ }^{16}$ Jensen (1989) famously distinguished "active” from "passive” investors. Active investors are those "who hold large equity or debt positions, sit on boards of directors, monitor and sometimes dismiss management, are involved with the long-term strategic direction of the companies they invest in, and sometimes manage the companies themselves." While not denying the importance of this distinction, Foss, Foss, and Klein (2007) argue that residual control rights make all resource owners "active," in the sense that they must exercise judgment over the use of their resources. In this approach, investors choose how "Jensen-active" they wish to be, which makes them "active" by definition.

Both Rothbard and Kirzner offer similar arguments. Writes Rothbard (1962, p. 538): "Hired managers may successfully direct production or choose production processes. But the ultimate responsibility and control of production rests inevitably with the owner, with the businessman whose property the product is until it is sold. It is the owners who make the decision concerning how much capital to invest and in what particular processes. And particularly, it is the owners who must choose the managers. The ultimate decisions concerning the use of their property and the choice of the men to manage it must therefore be made by the owners and by no one else.” Kirzner (1973, p. 68) makes a similar point about alertness: it can never be fully delegated. "It is true that 'alertness" . . . may be hired; but one who hires an employee alert to possibilities of discovering knowledge has himself displayed alertness of a still higher order. ... The entrepreneurial decision to hire is thus the ultimate hiring decision, responsible in the last resort for all factors that are directly or indirectly hired for his project.” Kirzner goes on to quote Knight (1921, p. 291): "What we call 'control' consists mainly of selecting some one else to do the 'controlling.,"
} 
anticipating future market conditions correctly, or at least more correctly than other entrepreneurs.

\section{Entrepreneurial teams}

Focusing on entrepreneurial action also responds to recent calls to link the theory of entrepreneurship more closely to the theory of group behavior (Stewart, 1989; Mosakowski, 1998; Cook and Plunkett, 2006). Some efforts to develop a theory of team entrepreneurship focus on shared mental models, team cognition, and other aspects of the process of identifying opportunities. Penrose’s (1959) concept of the firm's “subjective opportunity set” is an obvious link to judgment-based theories of entrepreneurship (Kor, Michael, and Mahoney, 2007). ${ }^{17}$ Entrepreneurs can also form networks to share expectations of the potential returns to projects (Greve and Salaff, 2003; Parker, 2007).

On the other hand, even if one views the perception of a (subjectively identified) opportunity as an inherently individual act, entrepreneurial action can be a team or group activity. Venture capital, later-stage private equity, and bank loans are often syndicated. Publicly traded equity is diffusely held. Professional-services firms and closed-membership cooperatives represent jointly owned pools of risk capital. Moreover, the firm’s top management team-to whom key decision rights are delegated — can be regarded as a bundle of heterogeneous human resources, the interactions among which are critical to the firm’s performance (Foss, Klein, Kor, and Mahoney, 2008).

This approach also suggests relationships between the theory of entrepreneurship and the theory of collective action (Olson, 1965; Hansmann, 1996). Once an entrepreneurial opportunity has been perceived, the entrepreneur may need to assemble a team of investors and/or a management team, raising problems of internal governance. Shared objectives must be formulated; different time horizons must be reconciled; free-riding must be mitigated; and so on. Cook and Plunkett (2006) and Chambers (2007) discuss how these problems are addressed within closed-

\footnotetext{
${ }^{17}$ Spender (2006) argues that "Penrose's model of managerial learning [is] an accessible instance of the epistemological approach proposed by Austrian economists such as Hayek, Kirzner, and Schumpeter.”
} 
membership, or “new-generation” cooperatives. Traditionally organized, open-membership cooperatives suffer from what Cook (1995) calls "vaguely defined property rights.” Because their equity shares are not alienable assets that trade in secondary markets, traditional cooperatives suffer from a particular set of free-rider, horizon, portfolio, control, and influence costs problems. ${ }^{18}$

In response, a new type of cooperative began to emerge in the 1990s. These new-generation cooperatives required up-front equity investments (in traditional cooperatives, equity is generated ex post, through retained earnings), restricted patronage to member-investors, and allowed for limited transferability of investment and delivery rights. ${ }^{19}$ One of the key challenges in developing new-generation cooperatives is the establishment of a founding investment team with shared objectives and constraints and an effective governing board. According to project champions - those entrepreneurs who formulated the original vision of the organization-the biggest obstacle they faced was convincing other farmer-investors, with whom they had close social ties, to invest (Chambers, 2007). In other words, the successful movement from opportunity identification to entrepreneurial action depended critically on transaction cost and collective action considerations, social capital, and reputation. Team entrepreneurship, in the Knightian sense described above, is a subset of the general theory of economic organization.

\section{Summary and conclusions}

The arguments presented here suggest that the entrepreneurship literature may have overemphasized the origins and characteristics of entrepreneurial opportunities. Instead, opportunities can be usefully treated as a latent construct that is manifested in entrepreneurial action, namely the exercise of judgment over the arrangement of heterogeneous capital assets. The Austrian theory of capital, interpreted in the "attributes" framework described above, provides a useful bridge between the Knightian theory of entrepreneurship and the theory of economic organiza-

\footnotetext{
${ }^{18}$ See Cook and Iliopoulos (2000) and Cook and Chaddad (2004) for details.

${ }^{19}$ Cook, Klein, and Chambers (2005) document the emergence of a cluster of new-generation cooperatives in Renville County, Minnesota.
} 
tion. In short, this paper suggests a re-orientation of the entrepreneurship literature toward deeds, not words or dreams. In Rothbard's (1985, p. 283) words: “Entrepreneurial ideas without money are mere parlor games until the money is obtained and committed to the projects.” Of course, the subjectivist concept of resources is inextricably tied to beliefs_-vision, imagination, new mental models, if you like-but these beliefs are relevant only to the extent that they are manifest in action.

One objection to this approach is to invoke recent literature in behavioral economics and neuroeconomics. This literature takes preferences, not choices, as its unit of analysis, seeking to understand the psychological basis of preference, the consistency of preferences, and the like, rather than taking preferences as an irreducible primary. Likewise, a theory of opportunity identification could mimic the methods of behavioral economics and neuroeconomics. This is indeed a potentially fruitful avenue for entrepreneurship research. However, like behavioral economics, such an approach has more in common with applied psychology than economics per se. It may contribute to a general, interdisciplinary approach to entrepreneurship, but is not an integral part of the economic theory of entrepreneurship (see Gul and Pesendorfer, 2005, for a more general argument along these lines). 


\section{References}

Abell, Peter, Teppo Felin, and Nicolai J. Foss. 2007. "Building Microfoundations for the Routines, Capabilities, and Performance Links.” Managerial and Decision Economics, forthcoming.

Acs, Zoltan, and David B. Audretsch. 1990. Innovation and Small Firms. Cambridge, Mass.: MIT Press.

Alchian, Armen A. and Harold Demsetz. 1972. "Production, Information Costs, and Economic Organization.” American Economic Review 62: 777-94.

Audretsch, David B., Max Keilbach, and Erik Lehmann. 2005. Entrepreneurship and Economic Growth. Oxford: Oxford University Press.

Aldrich, Howard E. 1990. "Using an Ecological Perspective to Study Organizational Founding Rates.” Entrepreneurship Theory and Practice 14, no. 3: 7-24.

Alvarez, Sharon A., and Jay B. Barney. 2004. "Organizing Rent Generation and Appropriation: Toward a Theory of the Entrepreneurial Firm.” Journal of Business Venturing 19: 621-35.

Alvarez, Sharon A., and Jay B. Barney. 2007. "Discovery and Creation: Alternative Theories of Entrepreneurial Action.” Strategic Entrepreneurship Journal 1, nos. 1-2: 11-26.

Barney, Jay B. 1986. “Strategic Factor Markets: Expectations, Luck and Business Strategy.” Management Science 42: 1231-41.

Barzel, Yoram. 1968. “Optimal Timing of Innovation.” Review of Economic and Statistics 50: 348-55. 1968

Barzel, Yoram. 1997. Economic Analysis of Property Rights. Cambridge: Cambridge University Press.

Böhm-Bawerk, Eugen von. 1889. Positive Theory of Capital. North-Holland, Ill.: Libertarian Press, 1959.

Boulding, Kenneth. 1956. The Image: Knowledge in Life and Society. Ann Arbor: University of Michigan Press.

Cantillon, Richard. 1755. Essai sur la nature de commerce en géneral. Henry Higgs, ed. London: Macmillan, 1931.

Casson, Mark C. 1982. The Entrepreneur: An economic Theory. Oxford: Martin Robertson.

Casson, Mark C. 2000 An Entrepreneurial Theory of the Firm, in Nicolai J. Foss and Volker Mahnke, eds., Competence, Governance and Entrepreneurship: Advances in Economic Strategy Research. New York: Oxford University Press.

Casson, Mark C. 2007. “The Economic Theory of Entrepreneurship: A Systems View.” Journal of Management Studies, forthcoming. 
Casson, Mark C., and Nigel Wadeson. 2007. "The Discovery of Opportunities: Extending the Economic Theory of the Entrepreneur.” Small Business Economics 28, no. 4: 285-300.

Chambers, Molly L. 2007. Organizational Spawning: Investment In Farmer-Controlled Businesses. Ph.D. Dissertation, Department of Agricultural Economics, University of Missouri.

Coase, Ronald H. 1937. “The Nature of the Firm,” Economica (N.S.) 4: 386-405.

Companys, Yosem, and Jeffery McMullen. 2007. "Strategic Entrepreneurs at Work: The Nature, Discovery, and Exploitation of Entrepreneurial Opportunities.” Small Business Economics 28, no. 4: 301-22.

Cook, Michael L. 1995. “The Future of U.S. Agricultural Cooperatives: A Neo-Institutional Approach.” American Journal of Agricultural Economics 77, no. 5: 1153-59.

Cook, Michael L., and Fabio R. Chaddad. 2004. "Redesigning Cooperative Boundaries: The Emergence of New Models.” American Journal of Agricultural Economics 86, no. 5: 124953.

Cook, Michael L., and Costas Iliopoulos. 2000. "Ill-Defined Property Rights in Collective Action: The Case of US Agricultural Cooperatives.” In Claude Menard, ed., Institutions, Contracts and Organizations. Cheltenham, U.K.: Edward Elgar, pp. 335-48.

Cook, Michael L., Peter G. Klein, and Molly J. Chambers. 2005. “Organizational Emergence: The Case of Renville, Minn.” Working Paper, Division of Applied Social Sciences, University of Missouri.

Cook, Michael L., and Bradley Plunkett. 2006. "Collective Entrepreneurship: An Emerging Phenomenon in Producer-Owned Organizations.” Journal of Agricultural and Applied Economics 38, no 2: 421-28.

Dane, Erik, and Michael Pratt. 2007. "Exploring Intuition and Its Role In Managerial Decision Making.” Academy of Management Review

Dasgupta, Partha, and Joseph E. Stiglitz. 1980. "Industrial Structure and the Nature of Innovative Activity.” Economic Journal 90: 266-93.

Demsetz, Harold. 1983. “The Neglect of the Entrepreneur.” In Joshua Ronen, ed. Entrepreneurship. Lexington: Lexington Press.

Demsetz, Harold. 1988. "The Nature of the Firm Revisited." Journal of Law, Economics, and Organization 4: 141-62.

Earl, Peter E. 2003. “The Entrepreneur as a Constructor of Connections.” Advances in Austrian Economics 6: 113-30.

Ekelund, Robert B., Jr., and Robert F. Hébert. 1990. A History of Economic Thought and Method. Third edition. New York: McGraw-Hill. 
Ekelund, Robert B., Jr., and David S. Saurman. 1998. Advertising and the Market Process. San Francisco: Pacific Research Institute.

Foss, Kirsten, Nicolai J. Foss, and Peter G. Klein. 2007. "Original and Derived Judgment: An Entrepreneurial Theory of Economic Organization.” Organization Studies 28, no. 12: 18931912.

Foss, Kirsten, Nicolai J. Foss, Peter G. Klein, and Sandra K. Klein. 2007. "The Entrepreneurial Organization of Heterogeneous Capital.” Journal of Management Studies 44, no.7: 1165-86.

Foss, Nicolai J., and Peter G. Klein. 2005.."Entrepreneurship and the Economic Theory of the Firm: Any Gains from Trade?” In Rashjree Agarwal, Sharon A. Alvarez, and Olaf Sorenson, eds., Handbook of Entrepreneurship Research: Disciplinary Perspectives. Dordrecht: Springer.

Foss, Nicolai J., Peter G. Klein, Yasemin Y. Kor, and Joseph T. Mahoney. 2008. "Entrepreneurship, Subjectivism, and the Resource-Based View: Towards a New Synthesis.” Strategic Entrepreneurship Journal, 2, no. 1: 73-94.

Finkle T. A., and D. Deeds. 2001. "Trends in the Market for Entrepreneurship Faculty, 19891998.” Journal of Business Venturing 16: 613-30.

Friedman, Milton M. 1953. “The Methodology of Positive Economics.” In Friedman, Essays in Positive Economics. Chicago: University of Chicago Press.

Gaglio, M., and J. A. Katz. 2001. "The Psychological Basis of Opportunity Identification: Entrepreneurial Alertness.” Small Business Economics 16: 95-111.

Gartner, W. B., and K. H. Vesper. 1999. University Entrepreneurship Programs. Los Angeles: Lloyd Grief Center for Entrepreneurial Studies, University of Southern California.

Gompers, Paul A. 1995. "Optimal Investment, Monitoring, and the Staging of Venture Capital.” Journal of Finance 50, no 5: 1461-89.

Greve, Arent , and Janet W. Salaff. 2003. “Social Networks and Entrepreneurship.” Entrepreneurship Theory and Practice 28, no. 1: 1-22.

Gul, Faruk, and Wolfgang Pesendorfer. 2005. “The Case for Mindless Economics.” Working Paper, Department of Economics, Princeton University.

Hansmann, Henry. 1996. The Ownership of Enterprise. Cambridge, Mass.: Harvard University Press.

Harper, David. 1995. Entrepreneurship and the Market Process: An Inquiry into the Growth of Knowledge. London: Routledge.

Hills, G.E., G.T. Lumpkin, and R.P. Singh. 1997. "Opportunity Recognition: Perceptions and Behaviors of Entrepreneurs.” Frontiers of Entrepreneurship Research 17: 168-82. 
Hindle, K. 2004. "A Practical Strategy for Discovering, Evaluating, and Exploiting Entrepreneurial Opportunities: Research-Based Action Guidelines.” Journal of Small Business and Entrepreneurship 17: 267-76.

Holcombe, Randall G. 1992. "Political Entrepreneurship and the Democratic Allocation of Economic Re-sources.” Review of Austrian Economics 15: 143-59.

Jensen, Michael C. 1989. "Eclipse of the Public Corporation.” Harvard Business Review 67: 6174.

Judd, Kenneth L., Karl Schmedders, and Sevin Yeltekin. 2003. "Optimal Rules for Patent Races.” CMS-EMS discussion paper \#1343, Northwestern University.

Katz, J. A. 2003. "The Chronology and Intellectual Trajectory of American Entrepreneurship Education.” Journal of Business Venturing 18: 283-300.

Kaplan Steven N., and Per Strömberg. 2003. "Financial Contracting Theory Meets the Real World: An Empirical Analysis of Venture Capital Contracts.” Review of Economic Studies 70: 281-315.

Klein, Peter G., and Sandra K. Klein. 2001. "Do Entrepreneurs Make Predictable Mistakes? Evidence from Corporate Divestitures.” Quarterly Journal of Austrian Economics 4, no 2: 3-25.

Kihlstrom, Richard E., and Jean-Jacques Laffont. 1979. "A General Equilibrium Entrepreneurial Theory of Firm Formation Based on Risk Aversion.” Journal of Political Economy 87, no. 4: $719-48$.

Kirzner, Israel M. 1966. An Essay on Capital. New York: Augustus M. Kelley.

Kirzner, Israel M. 1973. Competition and Entrepreneurship. Chicago: University of Chicago Press.

Kirzner, Israel M. 1979. Perception, Opportunity and Profit: Studies in the Theory of Entrepreneurship. Chicago: University of Chicago Press.

Kirzner, Israel M. 1985. Discovery and the Capitalist Process. Chicago: University of Chicago Press.

Kirzner, Israel M. 1992. The Meaning of Market Process. London: Routledge.

Kirzner, Israel M. 1997. "Entrepreneurial Discovery and the Competitive Market Process: An Austrian Approach.” Journal of Economic Literature 35:60-85.

Klein, Peter G. 1999. “Entrepreneurship and Corporate Governance,” Quarterly Journal of Austrian Economics 2: 19-42.

Knight, Frank H. 1921. Risk, Uncertainty, and Profit. New York: August M. Kelley.

Knight, Frank H. 1936. “The Quantity of Capital and the Rate of Interest.” Journal of Political Economy 44: 433-63, 612-42. 
Koppl, Roger, and Richard N. Langlois. 2001. “Organizations and Language Games.” Journal of Management and Governance 5, nos. 3-4: 287-305.

Kor, Yasemin Y., Joseph T. Mahoney, and Steven C. Michael. 2007. "Resources, Capabilities, and Entrepreneurial Perceptions.” Journal of Management Studies 44, no. 7: 1187-212.

Kuratko, D. F. 2003. "Entrepreneurship Education: Emerging Trends and Challenges for the 21st Century.” White Paper, U.S. Association of Small Business Education.

Lachmann, Ludwig M. 1956. Capital and Its Structure. Kansas City: Sheed Andrews and McMeel, 1978.

Langlois, Richard N. 1998. "Personal Capitalism as Charismatic Authority: the Organizational Economics of a Weberian Concept.” Industrial and Corporate Change 7: 195-214.

Langlois, Richard N., and Nicolai J. Foss. 1999. "Capabilities and Governance: The Rebirth of Production in the Theory of Economic Organization.” Kyklos 52, no. 2: 201-18.

Langlois, Richard N. 2002. "Modularity in Technology and Organization." Journal of Economic Behavior and Organization 49, no. 1: 19-37.

Langlois, Richard N., and Metin Cosgel. 1993. "Frank Knight on Risk, Uncertainty, and the Firm: A New Interpretation.” Economic Inquiry 31: 456-65.

Lawson, Tony. 1997. Economics and Reality. London: Routledge.

Long, W., and W.E. McMullan. 1984. "Mapping the New Venture Opportunity Identification Process.” In J.A. Hornaday, ed., Frontiers of Entrepreneurship Research. Wellesley, Mass.: Babson College.

Loury, Glenn L. 1979. "Market Structure and Innovation.” Quarterly Journal of Economics 93: 395-410.

Mäki, Uskali. 1996. "Scientific Realism and Some Peculiarities of Economics.” Boston Studies n the Philosophy of Science 169: 425-45.

Marchal, Jean. 1951. "The Construction of a New Theory of Profit.” American Economic Review 41, no. 4: 549-65.

McGrath, Rita G., and Ian C. MacMillan. 2000. McGrath, R.G., and I. MacMillan. The Entrepreneurial Mindset. Cambridge, Mass.: Harvard Business School Press.

McMullen, Jeffery, Lawrence Plummer, and Zoltan Acs. 2007. "What is an Entrepreneurial Opportunity?” Small Business Economics 28, no. 4: 273-83.

McMullen, Jeffrey, and Dean A. Shepherd. 2006. "Entrepreneurial Action and the Role of Uncertainty in the Theory of the Entrepreneur." Academy of Management Review 31, no. 1: $132-52$. 
Menger, Carl. 1871. Principles of Economics. New York: New York University Press, 1985.

Meyer, David R. 2000. Hong Kong as a Global Metropolis. Cambridge: Cambridge University Press.

Mises, Ludwig von. 1912. The Theory of Money and Credit. London, Jonathan Cape, 1934.

Mises, Ludwig von. 1920 "Economic Calculation in the Socialist Commonwealth.” Trans. S. Adler. Auburn, Ala., Ludwig von Mises Institute, 1990.

Mises, Ludwig von. 1949. Human Action: A Treatise on Economics. New Haven: Yale University Press.

Mises, Ludwig von. 1951. "Profit and Loss.” In Mises, Planning for Freedom. South Holland, Ill.: Libertarian Press, 1952.

Mosakowski, Elaine. 1998. "Entrepreneurial Resources, Organizational Choices, and Competitive Outcomes.” Organization Science 9: 625-43.

O’Brien, Dennis. 1984. "The Evolution of the Theory of the Firm," in O’Brien, Methodology, Money and the Theory of the Firm, vol. 1. Aldershott, U.K.: Edward Elgar, 1994.

Olson, Mancur. 1965. The Logic of Collective Action: Public Goods and the Theory of Groups. Cambridge, Mass.: Harvard University Press.

Parker, Simon C. 2004. The Economics of Self-employment and Entrepreneurship. Cambridge: Cambridge University Press.

Parker, Simon C. 2007. "The Economics of Formal Business Networks.” Working Paper, Department of Economics and Finance, Durham University.

Penrose, Edith T. 1959. The Theory of the Growth of the Firm. New York: Wiley.

Ricketts, Martin. 1987. The New Industrial Economics: An Introduction to Modern Theories of the Firm. New York: St. Martin's Press.

Rothbard, Murray N. 1962. Man, Economy, and State: A Treatise on Economic Principles. Princeton, N.J.: Van Nostrand.

Rothbard, Murray N. 1985. "Professor Hébert on Entrepreneurship.” In Rothbard, The Logic of Action Two: Applications and Criticism from the Austrian School. Aldershott, U.K.: Edward Elgar 1997, pp. 245-53.

Rothbard, Murray N. 1995. An Austrian Perspective on the History of Economic Thought, volume 1: Economic Thought Before Adam Smith. Cheltenham, U.K.: Edward Elgar.

Salerno, Joseph T. 2007. “The Entrepreneur: Real and Imagined.” Working Paper, Ludwig von Mises Institute. 
Sarasvathy, S. D. 2001. "Causation and Effectuation: Toward a Theoretical Shift from Economic Inevitability to Entrepreneurial Contingency.” Academy of Management Review 26: 243-63.

Sautet, Frederic. 2001. An Entrepreneurial Theory of the Firm. London: Routledge.

Scharfstein, David. 1988. “The Disciplinary Role of Takeovers.” Review of Economic Studies 55: 185-99.

Schultz, T.W. 1975. "The Value of the Ability to Deal with Disequilibria." Journal of Economic Literature 13: 827-46.

Schultz, T.W. 1982. "Investment in Entrepreneurial Ability.” Scandinavian Journal of Economics 82: 437-48.

Schumpeter, Joseph A. 1911. The Theory of Economic Development: An Inquiry into Profits, Capital, Credit, Interest, and the Business Cycle. Cambridge, Mass.: Harvard University Press, 1934.

Schumpeter, Joseph A. 1939. Business Cycles: A Theoretical, Historical and Statistical Analysis of the Capitalist Process. New York: McGraw-Hill.

Schumpeter, Joseph A. 1942. Capitalism, Socialism, and Democracy. New York: Harper \& Row.

Shane, Scott. 2003. A General Theory of Entrepreneurship: the Individual-Opportunity Nexus. Cheltenham, U.K.: Edward Elgar.

Shane, Scott, and S. Venkataraman. 2000. "The Promise of Entrepreneurship as a Field of Research.” Academy of Management Review 25, no. 1: 217-26.

Shaver, Kelly G., and Linda R. Scott. 1991. "Person, Process, Choice: The Psychology of New Venture Creation.” Entrepreneurship Theory and Practice 16: 23-45.

Solomon, G.T., S. Duffy, and A. Tarabishy. 2002. "The State of Entrepreneurship Education in the United States: A Nationwide Survey and Analysis.” International Journal of Entrepreneurship Education 1: 1-22.

Spender, J. C. 2006. “The RBV, Methodological Individualism, and Managerial Cognition: Practicing Entrepreneurship. Working Paper.

Stewart, Alex. 1989. Team Entrepreneurship. Newbury Park, Calif.: Sage.

Stigler, George J. 1961. "The Economics of Information.” Journal of Political Economy 69, no. 3: 213-25.

Stigler, George J. 1962. “Information in the Labor Market.” Journal of Political Economy 70, no. 5: 94-105. 
Thornton, Mark. 1998. "Richard Cantillon and The Origins of Economic Theory.” Journal des Economistes et des Etudes Humaines: 61-74

Witt, Ulrich. 1998a. "Imagination and Leadership: the Neglected Dimension of an Evolutionary Theory of the Firm." Journal of Economic Behavior and Organization 35: 161-77.

Witt, Ulrich. 1998b. “Do Entrepreneurs Need Firms?” Review of Austrian Economics 11: 99109.

Witt, Ulrich. 2003. "Market Opportunity and Organizational Grind: The Two Sides of Entrepreneurship." Advances in Austrian Economics 6: 131-51.

Xue, Jian-Hong, and Peter G. Klein. 2007. “A Latent-Variables Approach to Entrepreneurship.” Working Paper, Contracting and Organizations Research Institute, University of Missouri. 